\title{
Nutrient fluxes to the Bay of Biscay from Cantabrian rivers (Spain)
}

\author{
Ricardo PREGO*, Javier VERGARA \\ Instituto de Investigaciones Marinas (CSIC), 36208 Vigo, Spain \\ (E-mail: prego@iim.csic.es)
}

(Revised 26/02/98, accepted 27/02/98)

\begin{abstract}
Nutrient fluxes to the Bay of Biscay from the Cantabrian basin have been quantified for the first time. Data between 1981 and 1995 of the main 16 Cantabrian rivers from the COCA monitoring programme have been used. Values of water flow and dissolved inorganic nitrogen (DIN), phosphate and silicate concentrations have been taken. Equations are proposed to quantify the fluvial nutrient contributions to the Cantabrian Sea. The annual average of continental outputs to the Bay of Biscay from the Cantabrian basin is $16.1 \times 10^{9} \mathrm{~m}^{3}$ of freshwater, $1.0 \times 10^{9} \mathrm{~mol}$ of N in DIN, $0.062 \times 10^{9} \mathrm{~mol}$ of phosphate and $1.2 \times 10^{9}$ mol of silicate. In comparison with the French rivers, those of the Cantabrian have small fluxes and their outflow is very disperse, not forming large coastal plumes. From April to September, when the primary production is relatively important, the DIN contribution to the Cantabrian coastal reservoir is $10 \%$. Coastal fertilisation due to continental waters could be considered as negligible and only influences areas very close to river mouths, except for the Nalón River. Its flux represents $33 \%$ of nitrate, $39 \%$ of phosphate and $15 \%$ of silicate of the total continental inputs of nutrients to the Cantabrian Sea. (C) Elsevier, Paris
\end{abstract}

\section{nitrate / phosphate / silicate / river / Cantabrian coast}

Résumé - Flux de nutriments du bassin versant Cantabrique au golfe de Gascogne. Les flux de nutriments du bassin Cantabrique au golfe de Gascogne sont quantifiés pour la première fois. Collectées entre 1981 et 1995 dans le cadre du programme de surveillance COCA, les données utilisées sont les débits des seize principaux fleuves et leurs concentrations en azote inorganique dissous (DIN), en phosphate et en silicate. Des équations sont proposées pour quantifier les flux de nutriments. En moyennes annuelles, les apports continentaux sont estimés à $16,1 \times 10^{9} \mathrm{~m}^{3}$ d'eau douce, $1,0 \times 10^{9}$ mol d'azote inorganique dissous, $0,062 \times 10^{9} \mathrm{~mol}$ de phosphate et $1,2 \times 10^{9} \mathrm{~mol}$ de silicate. Comparée à celle des fleuves français, la contribution des fleuves espagnols est faible et très dispersée, sans grands panaches côtiers. Entre avril et septembre, par forte production primaire, l'apport d'azote inorganique dissous au réservoir côtier Cantabrique est de $10 \%$ du total. La fertilisation côtière par les eaux continentales est négligeable en dehors des embouchures de fleuves, sauf pour le Nalon ; celui-ci apporte à la mer Cantabrique $33 \%$ du nitrate, $39 \%$ du phosphate et $15 \%$ du silicate. (C) Elsevier, Paris

nitrate / phosphate / sillicate / fleuve / côte Cantabrique

\section{INTRODUCTION}

The general knowledge of chemical mass balance [12] in major world rivers contributing to the ocean [11] and, particularly, the nitrogen and phosphorus river fluxes [13] are substantial. There is far less information, hovewer, on small water flows, which may have an important local bearing as regards coastal fertilisation. An example of this is the case of the Bay of Biscay. There are complete studies on nutrients and the quality of the waters running into the bay from the French large rivers, such as the Loire [5, 15] and the Garonne [9, 17]. Conversely, the flow of nutritive elements from the Cantabrian fluvial basin is practically unknown. In this part of the Bay of Biscay flow a countless number of small water courses. These may be classified [16] as small rivers (with an

* Correspondence and reprints 
average annual flow of between 10 and $100 \mathrm{~m}^{3} \cdot \mathrm{s}^{-1}$ ) and streams (between 1 and $10 \mathrm{~m}^{3} \cdot \mathrm{s}^{-1}$ ). Biologically orientated works on phytoplankton and primary production have hardly considered nutrient flux into the Cantabrian coast. The winter mixing in terms of the spring bloom $[6,7]$ and the upwellings [3] were the only nutrient sources taken into consideration and the contribution of the rivers in coastal fertilization was not considered.

The recent trend to perform biogeochemical balances in land-coastal margin systems [21] and river outputs [14] requires quantification and evaluation of the continental contributions. The only overall estimate available in the Spanish coastal zone of the Bay of Biscay attributes to rivers the $6-7 \%$ of total nitrate and phosphate contribution to the Cantabrian coast during summer [19]. Although local studies also exist $[2,4]$, it is necessary to quantify and discuss the importance of river contributions of nutrients to the Cantabrian coastal environment. This is dealt with for the first time in this paper.

\section{SURVEY AREA AND DATA}

The Spanish coast of the Bay of Biscay (figure I) is $1230 \mathrm{~km}$ long, from Galicia to France. Its continental shelf is narrow, ranging from 15 to $40 \mathrm{~km}$ wide. Several short but relatively large rivers flow out along the coast shaping the Cantabrian fluvial system, which covers an area of $19000 \mathrm{~km}^{2}$. In general, these rivers occupy small basins. Thus, 17 basins have less than $1000 \mathrm{~km}^{2}$ of surface (table $I$ ), the surface of five basin (Deva, Navia, Nervión, Saja and Sella) ranges between 1000 and $2000 \mathrm{~km}^{2}$; the Nalon basin is the exception with a surface of $4866 \mathrm{~km}^{2}$.

The Cantabrian has an Atlantic-type rainfall system [20] with slight nivopluvial influences as it rises in the Cantabrian Range and in the Basque Mountain System ( $>1600 \mathrm{~m}$ altitude). The average annual flow is low, below $40 \mathrm{~m}^{3} \cdot \mathrm{s}^{-1}$, excepting Nalón and Navia (table ). The Cantabrian rivers are typical of an oceanic climate and there is approximately three times less flow in the dry than in the wet season. Therefore, when estimating the coastal contributions of nutrients, it is useful to consider two periods: The first, the phytoplankton activity period, lasts from April to September, according to primary production values and chlorophyll concentrations [6]. The nutrient rivers fertilisation may influence greatly the photosynthesis in Cantabrian coastal waters. The second period is the rainy period from November to February, when precipitations and river flows are highest. The more important nutrient river output to the Cantabrian coast must occur then.

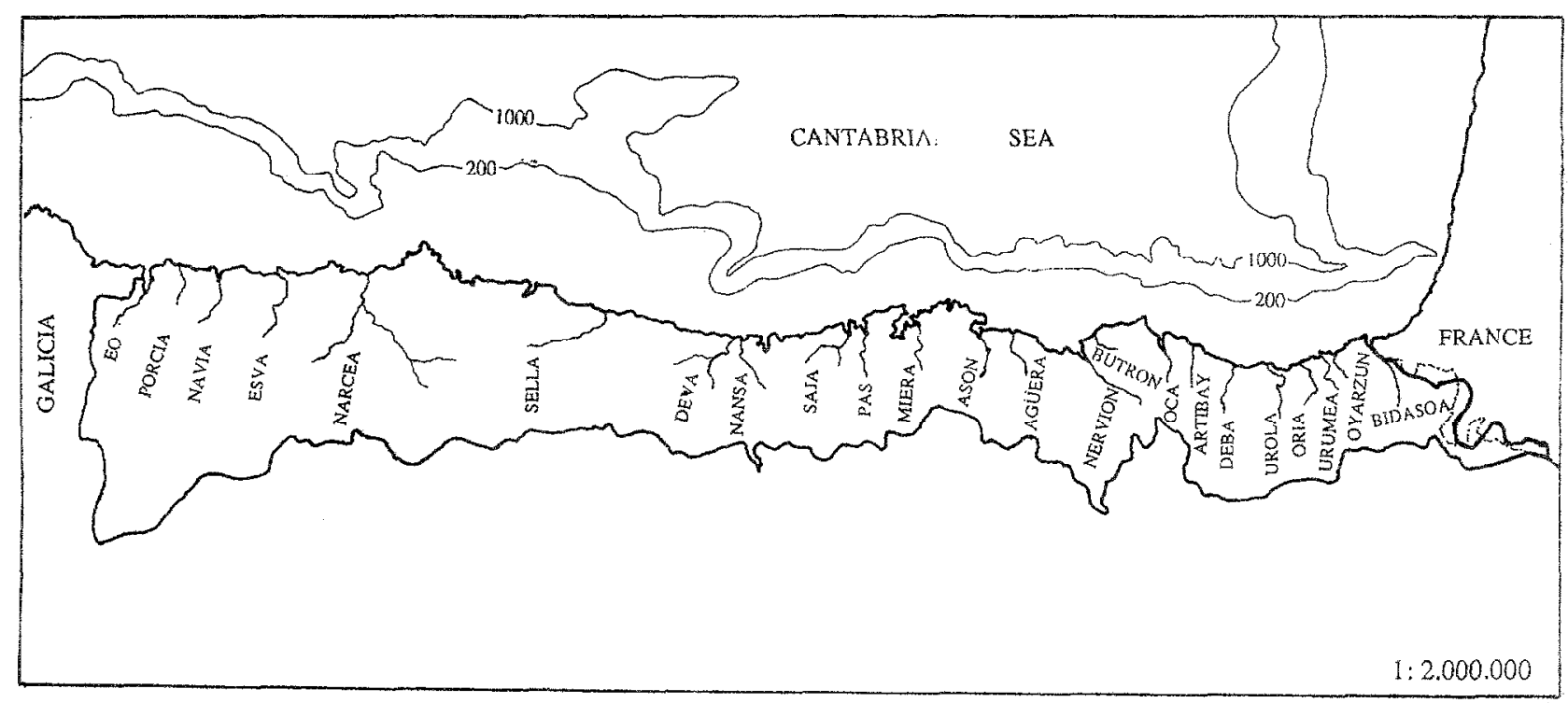

Figure 1. The Cantabrian fluvial basin covers a surface area of $19000 \mathrm{~km}^{2}$. Its short rivers run $17 \times 10^{9} \mathrm{~m}^{3} \cdot \mathrm{y}^{-1}$ into the $S$ panish coast of the Bay of Biscay. 
Tahle I. Surface catchment area, annual average flow and nutrient concentration ranges of Cantabrian rivers.

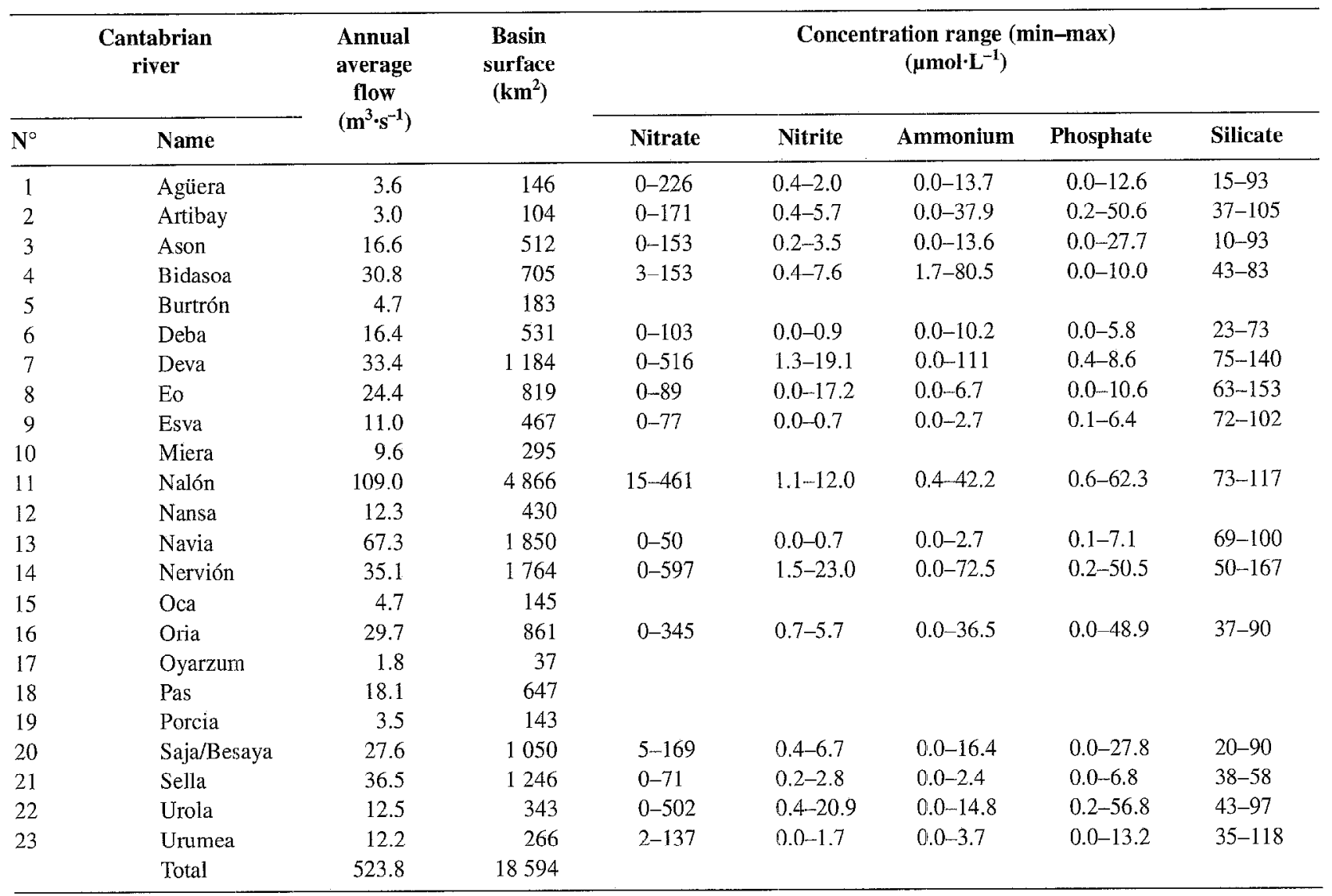

\section{DATA AND METHOD}

Data used in this study have been kindly provided by the 'Comisaría de Aguas del Norte de España' (CANE). These data from the COCA network derive from a monitoring programme of the physico-chemical parameters in Spanish rivers which runs into the Bay of Biscay. Measurements were obtained from sampling stations always near the mouth of the rivers. Data were recorded monthly and cover the period 1981-1995. From the available information only data on flows, nitrate, nitrite, ammonium, phosphate and silicate concentrations of the 16 main rivers in the Cantabrian basin are discussed here (table I). These 16 rivers represent $89.9 \%$ of watershed fluvial surface and $89.6 \%$ of river flows to the Cantabrian Sea. Nutrient concentrations measured in freshwater have been only considered. If chlorinity has shown the presence of brackish water, the data have been discarded.

Quantification of the river contribution of nutrients to the Cantabrian coast is based on the calculation of fluxes $(F)$ as the product of the freshwater flow $(Q)$ multiplied by their concentration $(C)$ of dissolved inorganic nitrogen (DIN), phosphate or silicate. The flux values for nutrients were studied as a function of flow (table II), using monthly data of 15 years of COCA network. This type of line has been the most appropriate when seeking the $F$ relationship with $Q$ for data on these three nutrients in the Cantabrian rivers. Chemical flux is applied as a function of the flow of the river and thus enables estimation of the annual averaged fluxes from their annual averaged flows.

\section{RESULTS AND DISCUSSION}

\subsection{Nutrient river concentrations}

Nutrient concentration ranges in Cantabrian rivers are found in table I. There is no relation between river flow and nutrient high values. Nalón, Nervión and Urola are very rich in inorganic nitrogen and phosphorus, Artibay and Oria in phosphates, Urola in nitrate and phosphate, 

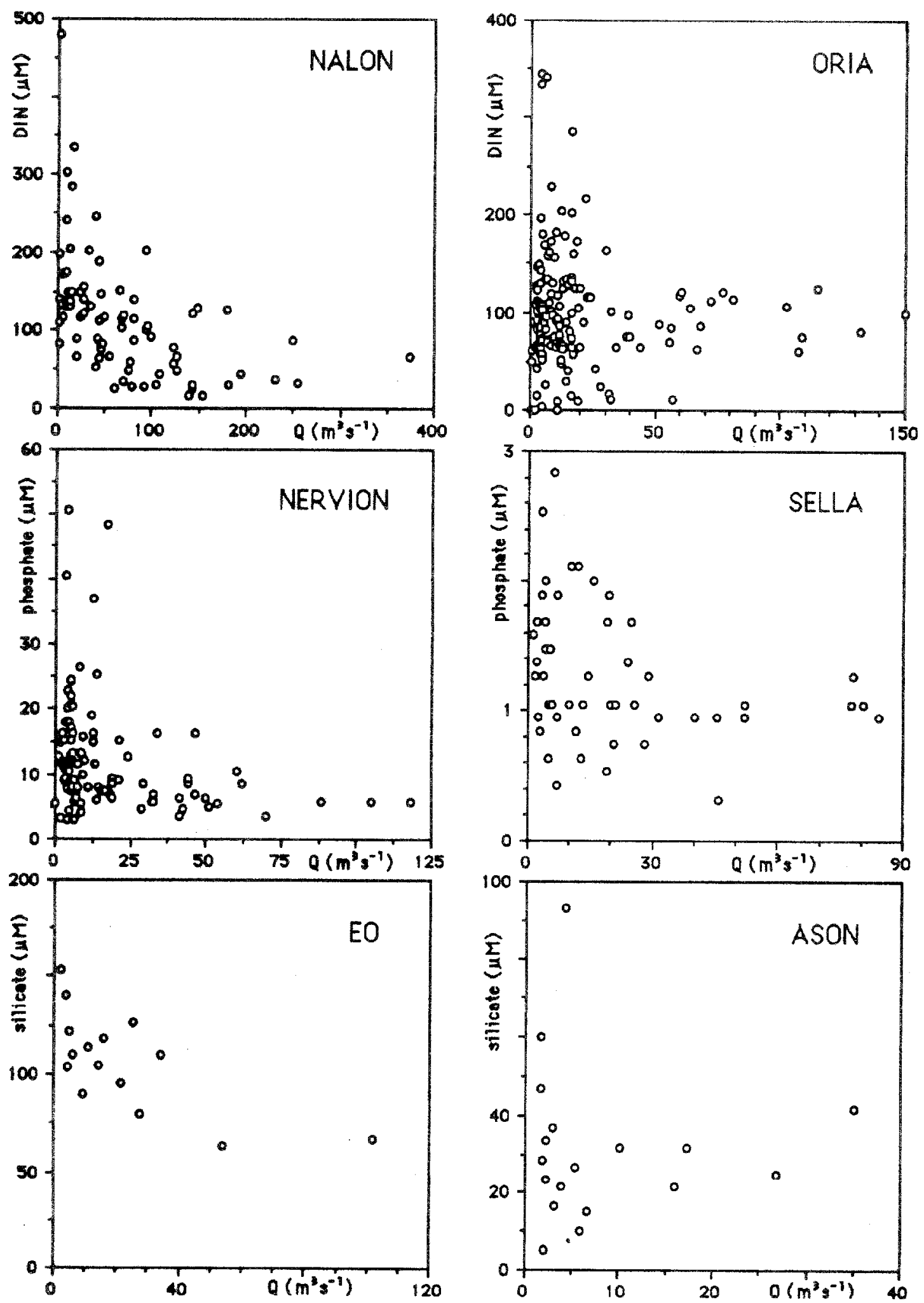

Figure 2. Various patterns of nutrient concentrations with water discharge from the rivers on the Cantabrian slope (data from the 'Comisaria de Aguas del Norte de España'). 
Table II. Equations for calculating the nutrient outputs into the Bay of Biscay by each Cantabrian river.

\begin{tabular}{|c|c|c|c|c|c|c|c|c|c|c|c|c|}
\hline $\mathbf{N}^{\circ}$ & $\begin{array}{c}\text { Cantabrian } \\
\text { river } \\
\text { Name }\end{array}$ & \multicolumn{11}{|c|}{$\mathbf{F}=\mathbf{a}+\mathbf{b} \times \mathbf{Q}+\mathbf{c} \times \mathbf{Q}^{2}$} \\
\hline 1 & Agüera & 45 & 37 & 0.87 & 0.964 & 25 & -0.93 & 0.32 & 0.944 & 0 & 71 & 0.976 \\
\hline 2 & Artibay & -7 & 114 & -3.36 & 0.841 & 1.2 & 2.58 & -0.18 & 0.587 & -10 & 86 & 0.967 \\
\hline 3 & Ason & 30 & 39 & & 0.923 & 0.7 & 1.10 & & 0.811 & -61 & 42 & 0.851 \\
\hline 6 & Deba & 138 & 89 & 0.20 & 0.959 & 61.5 & 1.68 & 0.07 & 0.919 & 42 & 94 & 0.968 \\
\hline 7 & Deva & 121 & 13 & 0.20 & 0.829 & -1.8 & 1.93 & & 0.884 & 21 & 47 & 0.932 \\
\hline 8 & Eo & -65 & 32 & 0.06 & 0.813 & 4.8 & 1.26 & & 0.908 & 468 & 65 & 0.925 \\
\hline 9 & Esva & -87 & 40 & & 0.810 & 4.3 & 0.54 & 0.02 & 0.847 & -99 & 105 & 0.997 \\
\hline 11 & Nalón & 1209 & 56 & & 0.648 & 131.1 & 8.45 & -0.02 & 0.570 & 110 & 75 & 0.999 \\
\hline 21 & Sella & 5 & 23 & 0.04 & 0.671 & 3.2 & 1.01 & & 0.897 & 63 & 41 & 0.830 \\
\hline 22 & Urola & 2 & 102 & & 0.938 & 10.6 & 2.70 & 0.01 & 0.789 & 57 & 60 & 0.977 \\
\hline 23 & Urumea & -35 & 40 & 0.03 & 0.910 & -0.9 & 1.37 & -0.01 & 0.819 & -64 & 107 & 0.953 \\
\hline
\end{tabular}

F: the nutrient flux in mmol $\cdot \mathrm{s}^{-1}$; Q: the freshwater flow in $\mathrm{m}^{3} \cdot \mathrm{s}^{-1} ; R^{2}$ : the linear regression coefficient; D.I.N.: dissolved inorganic nitrogen.

Deva in inorganic nitrogen and Bidasoa in ammonium. The silicate concentrations $(15-167 \mu \mathrm{M})$ are usual in natural rivers.

Evaluation of the possible nutrient enrichment of the Cantabrian rivers may be deduced from the concentrations. Deva, Nervión, Nalón and Urola are probably the most affected by anthropogenic inputs of nitrate and phosphate. Their average nitrate concentration is between 10 and 25 times greater than the levels noted by Meybeck [13] for the natural levels in unpolluted rivers. Conversely, the Deba, Esva, Navia and Sella Rivers contain the most unpolluted waters with nutrients.

The diagrams of freshwater river flows versus their nutrient concentrations, i.e. caudal-concentration (QC) distributions, show examples of typical profiles in Cantabrian rivers (figure 2). In general, these diagrams show patterns of nutrient concentrations with water discharge as described by Meybeck et al. [16]: DIN, as Oria in figure 2, shows a limited increase or a falloff in concentration at high discharges. This is the case of all Cantabrian rivers except for Deba, Esva and Navia, which present a cloud of points and Deva and Nalón (see Q-DIN diagram for Nalón in figure 2), which, exceptionally, have a phosphate-type profile. This profile corresponds to situations of point source discharges, such as municipal sewage. In these profiles the phosphate QC curve shows a general decrease in concentration with discharge, which implies increasing dilution of a substance introduced at a constant rate [16]. It is the case of all rivers for phosphate (such as Nervión; figure 2), except Besaya and Esva, which have a profile similar to the Sella in figure 2. Navia shows a cloud of points. Finally, silicate usually presents a phosphate type (such as Eo or Ason in figure 2), but the number of dates available are scarce in comparison with the other nutrients.

At low river discharge, the range of nutrient concentration is high. It could be due, as occurs in estuaries [1], to the increase of photosynthetic activity of freshwater phytoplankton, the remineralisation of organic matter or a higher anthropogenic influence in summer when the water flow is low.

Although nitrite and ammonium may also have a coastal fertilising effect, their fluxes to the Cantabrian Sea have not been significant due to their whole low concentration (Cantabrian river average is $92 \%$ of nitrate in DIN). Nitrite and ammonium percentage varies from $14 \%$ of DIN for Deva and Nalón to $4 \%$ of DIN for Sella and Saja. Nitrate is therefore the main source of inorganic river nitrogen to the Cantabrian coast, as generally occurs in river waters $(>84 \%$ of the inorganic nitrogen corresponds to nitrate [13]). 


\subsection{Nutrient river inputs to Cantabrian Sea}

To calculate the fluvial inputs to the Cantabrian Sca and to provide an estimation of the inputs of each river, the equations indicated in table II have been obtained. For phosphate and DIN, the best fitting corresponds to quadratic equations and to silicate linear equations.

According to the annual averaged flows shown in table $I$ and the equations in table II, the main contribution of nutrients to the sea is due to 1) the Nalon River, with fluxes of $7.3 \mathrm{~mol} \cdot \mathrm{s}^{-1}$ of $\mathrm{N}$ and $0.81 \mathrm{~mol} \cdot \mathrm{s}^{-1}$ of $\mathrm{P} ; 2$ ) the Nervión River with $4.5 \mathrm{~mol} \cdot \mathrm{s}^{-1}$ of $\mathrm{N}$ and $0.25 \mathrm{~mol} \cdot \mathrm{s}^{-1}$ of $\mathrm{P} ; 3$ ) the group of rivers comprising the Bidasoa, Deba, Navia, Oria, Saja and Urola with flows of $3.0-1.3 \mathrm{~mol} \cdot \mathrm{s}^{-1}$ of $\mathrm{N}$ and $0.11-0.05 \mathrm{~mol} \cdot \mathrm{s}^{1}$ of $\mathrm{P}$; 4) the remain water courses presenting low values, $0.8-0.2 \mathrm{~mol} \cdot \mathrm{s}^{-1}$ of $\mathrm{N}$ and $<0.04 \mathrm{~mol} \cdot \mathrm{s}^{-1}$ of P. Silicate fluxes are in accordance with river flows (figure 3). This figure shows the natural concentrations of silicate, as may be expected since this nutrient is not altered by anthropogenic influences. Thus, to estimate the silicate inputs of all the rivers, it is possible to calculate the flux of seven rivers without silicate concentration values using the equation of figure 3. The opposite occurs with phosphate and DIN whose concentration should be affected by urban waste and agricultural fertilisers. For these, a correction is made according to the river flow without DIN or phosphate information. The

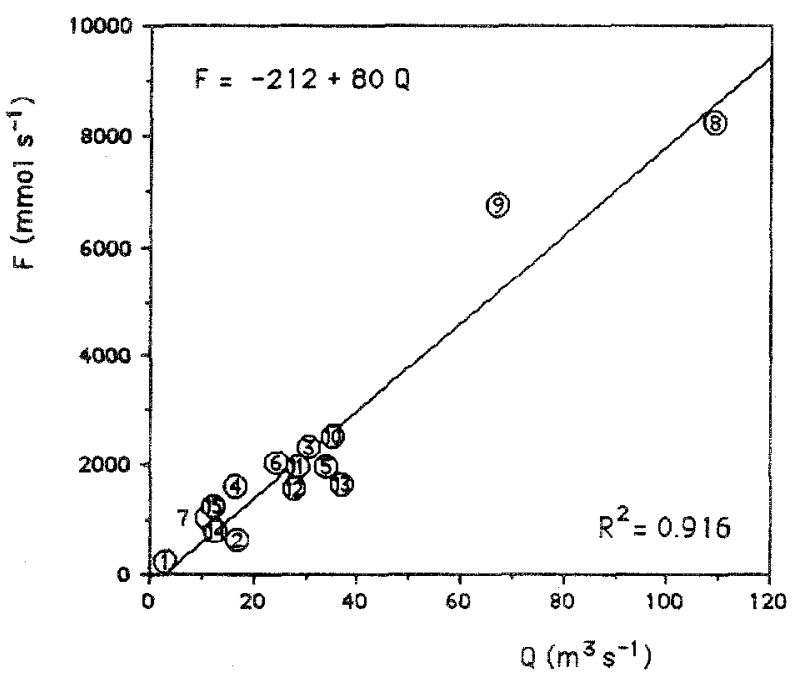

Figure 3. Annual average of silicate flux versus flow for Cantabrian rivers. They are indicated by their number in table I. Data are fitted to a straight line. Silicate flux for rivers without silicate values could be estimated from their flows in table $I$ and the equation $\mathrm{F}$.

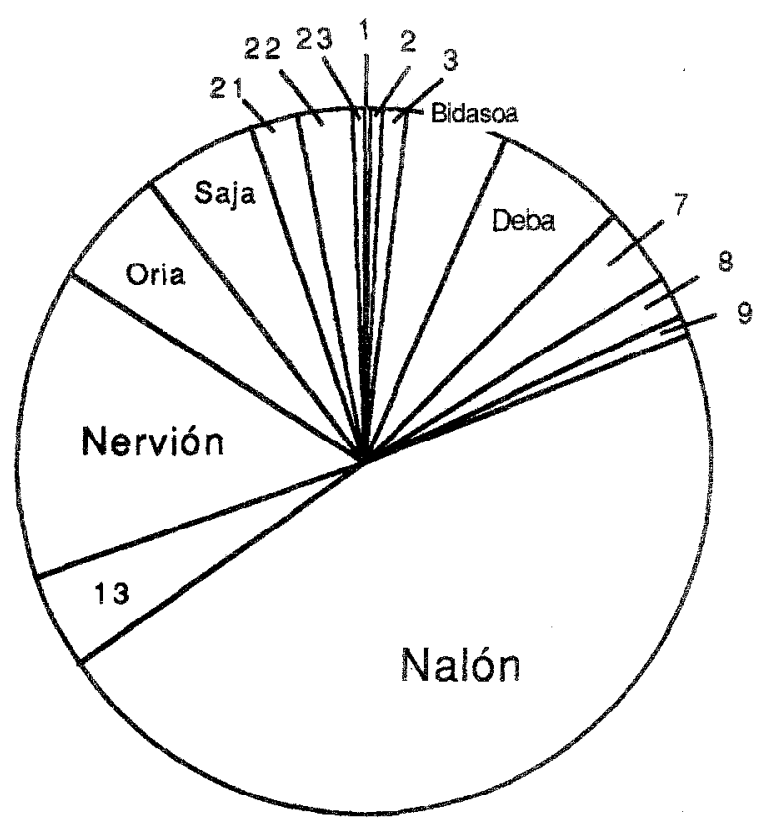

phosphate

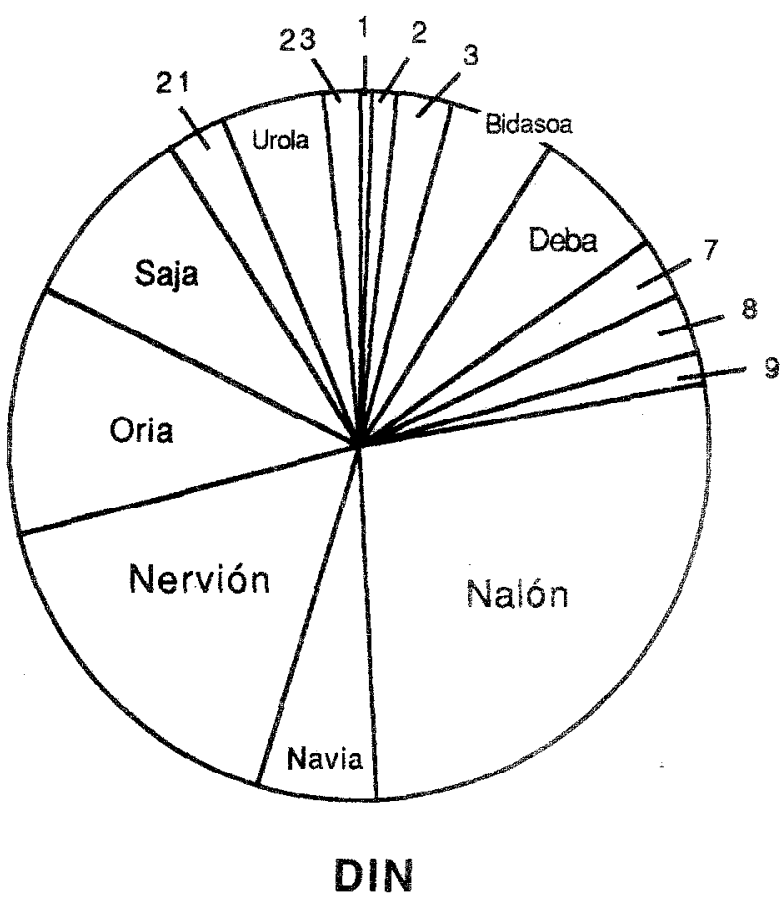

Figure 4. Annual relative importance of dissolved inorganic nitiogen (DIN) and phosphate Cantabrian river contributions to the Bay of Biscay. If lower than $5 \%$, only the river number is indicated as in table 1 . 
Table III. Annual estimation of the freshwater and nutrients inputs in the Bay of Biscay by Cantabrian rivers for the period $1981-1995$.

\begin{tabular}{ccccc}
\hline Input in Cantabrian Sea & $\begin{array}{c}\text { Rivers flow } \\
\left(\mathbf{m}^{3} \cdot \mathbf{s}^{-1}\right)\end{array}$ & $\begin{array}{c}\text { DIN flux } \\
\left(\mathbf{m o l}^{-1} \mathbf{s}^{-1}\right)\end{array}$ & $\begin{array}{c}\text { Phosphate flux } \\
\left(\mathbf{m o l} \cdot \mathbf{s}^{-1}\right)\end{array}$ & $\begin{array}{c}\text { Silicate flux } \\
\left(\mathbf{m o l} \cdot \mathbf{s}^{-1}\right)\end{array}$ \\
\hline Annual average & $524 \pm 123$ & $33.1 \pm 9.4$ & $1.95 \pm 0.53$ & $38.0 \pm 8.7$ \\
\hline
\end{tabular}

DIN: dissolved inorganic nitrogen.

annual average of resulting fluxes to the period 19811995 are shown in table III. There does not seem to be an obvious trend for these 15 years.

The annual continental contributions to the Bay of Biscay from the Cantabrian basin $\left(524 \mathrm{~m}^{3} \cdot \mathrm{s}^{-1}\right.$ of water) may be estimated as $1.0 \times 10^{9} \mathrm{~mol}$ of $\mathrm{N}, 0.062 \times 10^{9} \mathrm{~mol}$ of $\mathrm{P}$ and $1.2 \times 10^{9} \mathrm{~mol}$ of Si. The percentage importance of each river in the silicate contribution is similar to that of the flow, because of the good relation between both variables. Nevertheless, to DIN and phosphate it is different and is indicated in figure 4 .

Cantabrian fluxes are mainly due to the Nalón River, which contributes $33 \%$ of nitrate, $39 \%$ phosphate and $15 \%$ of silicate (figure 4 ). These are small values in comparison with the river contributions of nutrient salts from the French basin. Its two main rivers, the Loire $\left(838 \mathrm{~m}^{3} \cdot \mathrm{s}^{-1},[15]\right)$ and the Garonne $\left(761 \mathrm{~m}^{3} \cdot \mathrm{s}^{-1},[8]\right)$, each have an average annual flow almost double that of the Cantabrian basin. Nutrient fluxes are also far more significant: only the Loire River annually transports $6.4 \times 10^{9}$ mol of $\mathrm{N}$ of nitrate, $0.11 \times 10^{9} \mathrm{~mol}$ of $\mathrm{P}$ of phosphate and $14.6 \times 10^{9} \mathrm{~mol}$ of Si [15]. A further difference between the two basins is that the contribution from the Cantabrian basin into the Bay of Biscay is distributed among several small rivers and streams. The flow, therefore, is dispersed throughout the coastal area and no large coastal plumes are formed, as is the case on the French coast [9]. Data on surface salinity at the end of winter [10] just show a slight decrease in salinity in the coastal area adjacent to the Nalón River.

From April to September, when primary production is high in Cantabrian Sea waters [6], the importance of the continental source in coastal fertilisation could be evaluated from the DIN river contribution since it is usually the limiting nutrient in seawater. During this time period, the rivers inputs are $305 \mathrm{~m}^{3} \cdot \mathrm{s}^{-1}$ and $17.6 \mathrm{~mol} \cdot \mathrm{s}^{-1} \mathrm{~N}$ in DIN. This value is only $1 / 4$ and 2/3 of inputs to the Ria of Vigo in summer with and without upwelling [18], i.e. Cantabrian continental contributions of DIN are very low. Nitrate content in coastal waters of the Cantabrian Sea (0-50 m depth) in summer is $2.7 \times 10^{9} \mathrm{~mol}$ of $\mathrm{N} \mathrm{[19]} \mathrm{and}$ DIN river outputs to that coastal zone is $0.27 \times 10^{9} \mathrm{~mol}$ of $\mathrm{N}$ in DIN. Thus, it would justify approximately $10 \%$ of said total. These percentages suggest also the little overall importance of river contributions, as occurs in the Galician Sea, where runoff have similar rivers [22]. Taking into account other nutrients, the Cantabrian river inputs are $1.31 \mathrm{~mol} \cdot \mathrm{s}^{-1}$ of $\mathrm{P}$ and $22.6 \mathrm{~mol} \cdot \mathrm{s}^{-1}$ of Si. Therefore, it could be noted that there is no disequilibrium among nutrient fluxes to the sea. They are low and it may be assumed, in general, that the fertilising effect of landcoastal nutrient fluxes will only affect estuarine zones at the mouth of the Cantabrian rivers in spring and summer.

\section{Acknowledgements}

The authors thank the scientists of the CANE (Comisaria de Aguas del Norte de España) for their cooperation in providing us with the data required for this work and the kind suggestions of the referees. We also wish to thank Angeles García and Beatriz Cameselle for their technical assistance.

\section{REFERENCES}

[1] Aston S.R., Nutrients, dissolved gases, and general biogeochemistry in estuaries, in: Olausson E., Cato I. (Eds.), Chemistry and Biogeochemistry of Estuaries, Wiley \& Sons, Chichester, 1980, pp. 233-262.
[2] Azkona A., Tapia J.C., Water quality of rivers in the Basque Autonomous Community 1984-1985: quality objectives, river basin management, Adv. Water Pollut. Control 5 (1989) 103110 . 
[3] Botas I.A., Fernández E., Bode A., Anadón R, A persistent upwelling off the central Cantabrian coast (Bay of Biscay), Estuar. Coast. Shelf S. 30 (1990) 185-199.

[4] Cosme de Avilés A., Belzunce M.J., Estudio de la composición química del agua vertida al Mar Cantábrico por los rios de la cuenca norte del Pais Vasco, Cuadernos de Química Oceanográfica 1 (1996) 1-22.

[5] Crouzet P., L'eutrophisation de la Loire, Water Supply 1 (1983) 131-144.

[6] Fernández E., Bode A., Seasonal patterns of primary production in the Central Cantabrian Sea (Bay of Biscay), Sci. Mar. 55 (1991) 629-636.

[7] Fernández E., Bode A., Botas A., Anadón R., Microplankton assemblages associated with saline fronts during a sprintg bloom in the central Cantabrian sea: differences in trophic structure between water bodies, J. Plankton Res. 13 (1991) 1239-1256.

[8] Figueres G., Martin J.M., Meybeck M., Seyler P., A comparative study of mercury contamination in the Tagus estuary (Portugal) and Major French estuaries (Gironde, Loire, Rhône), Estuar. Coast. Shelf S. 20 (1985) 183 203.

[9] Gouleau D., Jouanneau J.M., Weber O., Apports en sels nutritifs d'une vasière de plate-forme, comparaisons avec les flux issus de l'estuaire de la Gironde, in: Sorbe J.C., Jouanneau J.M. (Eds.), Actes du II ${ }^{\mathrm{e}}$ Colloque international Océanographie du Golfe de Gascogne. Centre Régional de Publication de Bordeaux, Bordeaux, 1993, pp. 53-58.

[10] Grupo SARP., Datos básicos de hidrografía, nutrientes disueltos y material particulado en aguas superficiales de la costa de Galicia y Mar Cantábrico (N-NO de España), Informes Técnicos del I.E.O., n 143, (1993) 56 p.

[11] Mackenzic F.T., Garrels R.M., Chemical mass balance between rivers and oceans, Am. J. Sci. 264 (1966) 507-525.
[12] Martin 3.-M., Meybeck M., Flemental mass-balance of material carried by major world rivers, Mar. Chem. 7 (1979) 173206.

[13] Meybeck M., Carbon, nitrogen and phosphorus transport by world rivers, Am. J. Sci. 282 (1982) 401-450.

[14] Meybeck M., Helmer R., The quality of rivers: from pristine stage to global pollution, Palaeogeogr. Palaeoclim. Palaeoecol. 75 (1989) 283309

[15] Meybeck M., Cauwet G., Dessery S., Somville M., Gouleau D., Billen G., Nutrients (organic C, P, N, Si) in the eutrophic river Loire (France) and its estuary, Estuar. Coast. Shelf S. 27 (1988) 595-624.

[16] Meybeck M., Friedrich G., Thomas R., Chapman D., Rivers, in: Chapman D. (Ed.), Water Quality Assessments, Chapman \& Hall, London, 1992, pp. 238-316.

[17] Philips I., Qualité des eaux dans l'estuaire de la Gironde, thèse $3^{e}$ cycle, Université de Bordeaux, 1980.

[18] Prego R., Las sales nutrientes en las rias gallegas, Informes Técnicos Scientia Mar 157 (1990) 33.

[19] Prego R., Estimation approximative des flux des sels nutritifs aux eaux côtières de la mer Cantabre, in: Actes du $\mathrm{II}^{\mathrm{c}}$ Colloque international Océanographie du Golfe de Gascogne, Centre Régional de Publication de Bordeaux, Bordeaux, 1993, pp. 53-58.

[20] Terán de M., Solé L., Geografía General de España, Ariel, Barcelona, 1978, pp. 182-208.

[21] Ver L.M.B., Mackenzie F.T., Lerman A., Modeling pre-industrial C-N-P-S biogeochemical cycling in the land-coastal margin system, Chemosphere 29 (1994) 855-887.

[22] Vergara J., Prego R., Estimación de los aportes fluviales de sales nutrientes a la costa gallega, in: Prego R., Fernández J.M. (Eds.), Procesos biogeoquímicos en sistemas costeros hispano-lusos, Servicio de Publicaciones de la Diputación de Pontevedra, Pontevedra, 1997, pp. 33-40. 